\title{
MAGEC2 wt Allele
}

National Cancer Institute

\section{Source}

National Cancer Institute. MAGEC2 wt Allele. NCI Thesaurus. Code C104528.

Human MAGEC2 wild-type allele is located in the vicinity of Xq27 and is approximately 3 kb in length. This allele, which encodes melanoma-associated antigen C2 protein, may enhance ubiquitin ligase activity. The gene is frequently expressed in head and neck carcinomas, breast carcinomas, non-small-cell lung carcinomas, and sarcomas. 